\title{
LA POESÍA DE DYLAN THOMAS: ESTUDIO DE TEMAS Y TÉCNICAS POÉTICAS
}

ELENA LÓPEZ TORRES

Universidad de Cádiz

\section{RESUMEN}

Dos son los temas fundamentales que articulan la poesía de Dylan Thomas: por una parte, la absoluta indisolubilidad entre la vida y la muerte, la continuidad de los procesos orgánicos de creación / destrucción; en segundo lugar, la búsqueda de la trascendencia mediante la fe en Dios, búsqueda llena de contradicciones y no resuelta a lo largo de su producción poética. De las técnicas utilizadas por Dylan Thomas destacan la dialéctica de las imágenes, la ambigüedad circunstancial, semántica o sintáctica, la creación de metáforas elaboradas, el uso exhaustivo de aliteraciones, onomatopeyas, estructuras rítmicas y una gran variedad de rimas, y en resumen todo un conjunto de procedimientos destinados a oscurecer el acceso racional del lector al poema y a potenciar, por el contrario, su comprensión intuitiva $e$ inconsciente.

\section{BREVE PERFIL BIOGRÁFICO}

Dylan Thomas nació en Swansea, Gales, en octubre de 1914, poco después del comienzo de la Primera Guerra Mundial, en una familia de origen rural. Su padre, hombre autoritario y de compleja personalidad, era profesor de Lengua In- 
glesa en la escuela local; su gran afición por la poesía le llevaba a leer en voz alta a Dylan, cuando el niño aún no había cumplido los cuatro años, textos de Shakespeare y otros autores clásicos ingleses. Su madre, mujer bondadosa y sencilla, sentía verdadera admiración por su hijo, y contribuyó de manera fundamental en la formación de las vivencias de su niñez, estado que llegó a convertirse, a los ojos del poeta adulto, en el símbolo por excelencia del Paraíso Perdido.

Debido a sus problemas de salud, Dylan Thomas no acudió a la escuela hasta la edad de 11 años. Su desinterés por todo lo que no fuera Lengua y Literatura Inglesa se puso pronto de manifiesto. Tras siete años de eludir exámenes y faltar a clase, dejó la escuela en 1931.

Desde 1931 a 1934, fecha en que se traslad6 por primera vez a vivir a Londres, alternó la composición de poemas con el trabajo de reportero en el periódico local, South Wales Daily Post, así como con la participación como actor en la compañía de teatro Swansea Little Theatre, grupo no profesional. Este período, el más fértil de su vida de escritor, quedó reflejado en los numerosos cuadernos de ejercicios que escribió, y que ahora se conocen como los Notebook Poems. De ellos extrajo el material que constituyó su primer libro publicado, 18 Poems, que salió a la luz en diciembre de 1934. De ellos continuó extrayendo material a lo largo de toda su vida. También en esta época se inicia la correspondencia con Pamela Hansford Johnson, fundamental para conocer sus ideas acerca de la creación poética.

La publicación de 18 Poems constituyó un acontecimiento en el mundo literario, tanto por la originalidad de las imágenes que se presentaban, como por los temas que constituían el núcleo de las mismas, a saber, la identificación de los procesos orgánicos con las fuerzas del universo, expresado a través de inquietantes imágenes de vida pre-natal, nacimiento, muerte y resurrección.

En 1936 publicó su segundo volumen, Twenty-five Poems, muy similar al anterior, tanto en la técnica como en los temas abordados. En 1937 se casó con Caitlin Macnamara, y dos años más tarde publicó su tercer libro de poesías, The Map of Love, en donde el estilo empieza a cambiar hacia una menor densidad y concentración de imágenes, y aparecen temas nuevos como los derivados de la relación matrimonial y su reciente paternidad, así como poemas acerca de personas concretas. En 1940 publicó su primera colección de cuentos, todos de carácter autobiografico, bajo el título de Portrait of the Artist as a Young Dog.

Al estallar la Segunda Guerra Mundial, comenzó a escribir guiones para la BBC y para Strand Films, y a principios de 1941 empezó su segunda colección de historias cortas, Adventures in the Skin Trade. En 1943 nació su hija Aeronwy. Entre Julio del 44 y Septiembre del 45, la familia pudo volver a establecerse, a pesar de las dificultades económicas que en los años anteriores les habían ido obligando a alternar el lugar de residencia. El regreso a su tierra na- 
tal dio a Thomas, cuya inspiración poética se halló siempre a lo largo de su vida indisolublemente unida a los paisajes y a las vivencias de su infancia, el impulso necesario para superar los siete años de infertilidad anterior, y en 1946 apareció un nuevo volumen de poemas, Deaths and Entrances. En él se aprecia ya un cambio significativo en el estilo, que se caracterizará a partir de ahora por la mayor accesibilidad de los poemas, así como por una atmósfera de exaltación y sacramentalización de la naturaleza. De la misma época son también los guiones para la radio Quite Early One Morning y A Child's Christmas in Wales.

Tras un nuevo período de cinco años (durante los cuales la familia abandonó Gales para fijar su residencia en Londres primero y posteriormente en Oxford), en 1949, poco antes del nacimiento de su tercer hijo, vuelven a Gales, concretamente a Laugharne, instalándose en la famosa Boat House situada en un acantilado frente a la bahía. Allí escribí sus últimos poemas, así como Under Milk Wood, terminado en 1953, poco antes de ser leído por primera vez en el Poetry Centre de Nueva York.

Entre febrero y junio de 1950, agobiado por la situación familiar de penuria económica, realizó su primera gira por Estados Unidos, un asombroso éxito de público al cual contribuyeron no poco las dotes histriónicas y declamatorias del poeta por una parte, y sus constantes escándalos sexuales y etílicos por otra. Los sustanciosos ingresos obtenidos durante la gira fueron dilapidados por Thomas con la misma rapidez con que fueron recibidos. En 1952 repitió la experiencia con un éxito similar; ese año se publicó en Nueva York In Country Sleep, que reunía los seis poemas escritos desde 1946. De vuelta a Gran Bretaña, terminó el "Prólogo» en verso que preparaba para la publicación de un nuevo volumen, en el que se recogerían la mayoria de los poemas publicados hasta la fecha, junto con algunos inéditos. Tal volumen, el último de su vida, apareció con el título de Collected Poems, y tuvo una excelente acogida de crítica y público.

La enfermedad y la muerte de su padre, a quien siempre se había sentido muy unido, a finales de 1952 fue un rudo golpe para su estado de salud, cada vez más deteriorado. Durante la tercera gira por Estados Unidos en 1953 falleció en Nueva York el 9 de noviembre a la edad de 39 años, a consecuencia, al parecer, de una sobredosis de medicación administrada por el médico y por sí mismo para aliviar los síntomas (ahora ya cercanos al colapso) producidos por su alcoholismo.

\section{LA DIALECTICA VIDA/MUERTE Y EL TEMA RELIGIOSO EN LA POESfA DE Dylan Thomas}

Como se ha comentado, la poesía de Dylan Thomas evoluciona sensiblemente desde la primera colección de poemas publicada en 1934, 18 Poems, 
hasta In Country Sleep, volumen publicado en Nueva York en 1952, con anterioridad a la recopilación hecha por el mismo Dylan Thomas en Collected Po$e m s$, poco antes de su muerte.

Uno de los rasgos más característicos de sus primeros poemas es la oscuridad y aparente falta de sentido: las palabras parecen haberse convertido en organismos autónomos, en arquitectura verbal, habiendo perdido el nexo de unión con un referente identificable. $O$, como lo expresa Walford Davies:

Quite often, the early poems may seem to offer the reader only an impenetrable enigma. It is not, as with Eliot, a question of allusions to other works of literature that you need to track down; or, as with Yeats, a case of a poem beginning from some fairly accessible experience or emotion, but taking the reader on a journey into deeply mysterious territories. The problem often seems one of not knowing where a poem begins to engage a recognizable world of experience other than itself. Thomas will seem to make up a new language, using words, phrases and grammar altogether familiar in themselves, but positively arranged in a new way. (Davies $1986: 26$ )

Junto a esta oscuridad del lenguaje, aparece todo un mundo fantasmagórico y originalísimo en el que el tiempo, por ejemplo, aparece comparado a «a running grave» (When, like a running grave), sus labios «leech to the fountain head» (The force that through the green fuse drives the flower) o chupan «like a sponge» (When once the twilight locks no longer); en el que Cristo como representación de la vida habla antes incluso de existir como embrión (Before I knocked); en el que el hablante de uno de los poemas realiza un viaje de vuelta a la oscuridad de su herencia genética (I dreamed my genesis); en el que el protagonista poemático en otro declara que su mundo se reduce a una tumba (My World is Pyramid)... Un mundo extraño, en el cual el poeta

[...] seems to be arguing rhetorically with himself on the subject of sex and death, sin and redemption, the natural processes, birth and decay. At times he writes about religion as if he and the Druids, Christ and Adam, the chapel preachers and the devil were contemporaries. (Ackerman 1991: 43)

El hecho de que la gran mayoría de estos poemas fueran compuestos durante la adolescencia del poeta, parece haberlos dotado de algunas de sus características más peculiares:

To the young Thomas in the turbulence of his adolescence, man and external reality seemed so inter-involved as expressive forms that 
the images and metaphors for one were those for the other [...]. Feeling intensely that the processes of his own inner life were inseparably involved in the processes of external nature, Thomas [...] is preoccupied, sometimes obsessed, by that involvement. (Stephens 1972: 22-23)

La continuidad de los procesos orgánicos, la absoluta indisolubilidad entre la vida y la muerte, se constituyen, en sus primeros poemas, en el tema central. Su idea de proceso no es un término abstracto, sino la realidad misma de su cuerpo, reflejo de los mismos procesos que se desarrollan en la Naturaleza:

Thomas's idea of process is important. The term itself is rather mechanistic, as he uses it. He always takes the machine of energy rather than some abstraction, such as spirit or essence. Hence the concreteness of his words and images; obscurity occurs also because of the "process» of mixing the imagery of the subconscious with biological imagery, as in Hopkins. (Shapiro 1966: 174-5)

Esta visión del mundo como proceso, como fuerzas que interactúan en una dinámica constante de creación y destrucción, como ciclos de vida y muerte que se repiten una y otra vez, permanece constante en la poesía de Dylan Thomas, a pesar de la evolución formal de la misma, que tiende a una mayor simplicidad aparente con el paso del tiempo. Junto a este cambio en favor de una mayor inteligibilidad racional, la exaltación mecanicista de los procesos de la Naturaleza, característica de los primeros poemas, cede el lugar a una visión de la vida en la cual se manifiesta de forma clara el sentido de compasión hacia los seres humanos, junto con la búsqueda de la trascendencia mediante la fe en Dios, fe que se busca en algunas ocasiones a través de la creación poética misma (esa es la impresión última que parece producir el poema Vision and Prayer, por ejemplo: que el poeta ha escrito un poema acerca del nacimiento de su fe como un medio de hacer que esa fe que no posee nazca realmente), pero que no acaba de encontrar una expresión convincente en los poemas de Dylan Thomas, que insisten en el tema de la muerte y la vida como ciclos misteriosos, tal vez sagrados, con una amargura creciente y que contrasta de forma notable con el tono alegre, incluso ligeramente histérico (como en And Death Shall Have No Dominion, o el último verso de $A l l$, all and all the dry worlds lever) de algunos de los poemas de la primera etapa.

Claro que esto no deja de ser una apreciación personal. Otros críticos, como Ackerman por ejemplo, afirman, sin embargo que su poesía se sustenta sobre la base de la fe: 
The Puritanism at the heart of Welsh life produced in Thomas a literature of conflict. The attitudes in his poetry are sometimes Christian, sometimes anti-Christian: but even when the feeling is anti-Christian in attitude it is religious in temper, for the strong, racial Nonconformist spirit had given him a religious sense of profane existence. In his early poems he often speaks of himself as damned. He seems to be quarrelling with God and His Church, but belief in the reality of God and Christ is always there. It is something that, try as hard as he will, he cannot lose. (Ackerman 1991: 40)

Pero, con independencia del tema de la fe, existe en su poesía al mismo tiempo el uso recurrente de la imaginería cristiana:

Thomas called himself a 'holy maker', whose poems are written 'in praise of God'. Indeed, God and Christ are rarely absent from his service [...].Like Bunyan, Thomas was always asking what he could do to be saved. What, if not religious, would he want to ask that for? Clearly there is something so holy about some of his poems that critics cannot be blamed for detecting it. But holiness of what kind? [...] Like any vegetable-loving romantic, [...] Thomas found nature holy.

'The country is holy', he says in the prayer for his daughter. A statement of this kind is extraordinary; for he preferred images. Those he had acquired from the chapel and from Hopkins or Joyce were handy and suitable for expressing natural holiness -and so were sermon, prayer and ritual. God creates by the Word, and Jesus suffers for mankind. So too the poet. What better images for himself could he find? (Tindall 1961: 8-9)

Sin embargo, la imagen de Cristo es interesante para Dylan Thomas no sólo en cuanto representación del hombre que sufre en beneficio de la comunidad, sino en cuanto paradigma de los ciclos de muerte/resurrección presentes en la Naturaleza:

[...] martyrdom [...] becoming the sacrifice human beings undergo on their way to a death suffered in the name of the regeneration of nature, a sacrifice which is undistinguishable from that of the poet who pours his life into the abyss of language. ${ }^{1}$

1 KORG 1990: 26. Para un estudio de imágenes y temas en la poesía de Dylan Thomas tomados de la Biblia y el cristianismo, véase MOYNIHAN 1966. 
Junto con el uso poco convencional de los símbolos cristianos, se encuentran en los poemas de Dylan Thomas manifestaciones de una profunda desconfianza hacia la religión institucional. Parece existir en algunos de sus poemas una dicotomía entre la consideración de la figura de Cristo como símbolo de los procesos de muerte / resurrección, y la figura de Dios, cargada de connotaciones negativas. Muchos de sus poemas parecen sugerir que la idea de Dios es inseparable de la conciencia del tiempo, y con ella, de la pérdida de la inocencia y del miedo a la muerte. En el poema Incarnate devil, Dios y el diablo se presentan como las dos fuerzas que han hecho surgir la noción del tiempo; es esta conciencia del tiempo la que, a su vez, crea en el hombre la ilusión de que existe un cielo después de la muerte:

«[...] time has ticked a heaven round the stars $»^{2}$

Ideas similares a las de este verso, que pertenece al poema The force that through the green fuse drives the flower, se encuentran a todo lo largo de la producción poética de Thomas. En Then was my neophyte, Dios habla a Cristo:

'Time shall not murder you,' He said,

'Nor the green nought be hurt;

Who could hack out your unsucked heart,

$O$ green and unborn and undead?'

Pero la respuesta de éste no puede ser más desesperanzada:

I saw time murder me.

En It is the sinners' dust-tongued bell, el Cristo hombre contempla con la misma desesperanza el resultado de la unión entre Dios y el hombre:

I mean by time the cast and curfew rascal of our marriage, At nightbreak born in the fat side, from an animal bed

In a holy room in a wave;

2 «It is time, and the pressure of time, Thomas seems to be saying, that has caused man fancifully to invent the concept of 'heaven' or eternity (the last line originally read, simply, 'How time is all - all-important and all there is'). I at least think this reading accords with the general tone of the poem, with its acceptance of physical, rather than spiritual, truths.» DAVIES 1986: 29-31. Estas palabras de Walford Davies coinciden con la interpretación que se sugiere en el texto. 
Paralelamente a esta visión pesimista de la divinidad, encontramos también en sus poemas afirmaciones acerca de la moral como invención humana, frente a la evidente amoralidad de las leyes de la Naturaleza. En el poema This side of the truth, por ejemplo, el poeta se dirige a su hijo pequeño en los siguientes términos:

Good and bad, two ways

Of moving about your death

By the grinding sea,

Walford Davies afirma respecto a los poemas This side of the truth e Incarnate devil:

[...] these two poems challenge, with uncharacteristic pointedness, the choice man is traditionally enjoined to make between Good and Evil. The earlier poem implies, and the later poem affirms, that notions of Good and Evil are man's invention, superimposed on a morally neutral, though dynamic, universe. (Davies 1986: 61)

Un argumento similar es el que encuentra Raymond Stephens en el poema The force that through the green fuse drives the flower:

[the poem] in its argument neither praises nor condemns the lifeforce. It does not say that it is 'good' or 'bad'. Didactically, the poet cannot say what it is. His 'dumbness' is his inability to give a doctrinal explanation. (Stephens 1972: 38)

Y sin embargo, existen también en los poemas de Dylan Thomas ejemplos de aproximación al Dios de la doctrina cristiana. Es bien conocida la «Author's Note» que apareció junto con la edición de Collected Poems; en ella, Thomas afirma:

I read somewhere of a shepherd who, when asked why he made, from within fairy rings, ritual observances to the moon to protect his flocks, replied: 'I'd be a damn' fool if I didn't!' These poems, with all their crudities, doubts and confusions, are written for the love of Man and in praise of God, and I'd be a damn' fool if they weren't!

Para Aneirin Talfan Davies, esta afirmación («for the love of Man and in praise of God») no pasaría de ser «a hollow mockery» de no estar sustentada en la convicción profunda acerca del papel que corresponde al hombre en la je- 
rarquía del universo creado por Dios ${ }^{3}$. Es cierto que existe en su poesía una evolución hacia la expresión cada vez más recurrente, en los últimos poemas, de la Naturaleza como «a sacramental universe in which the common things of life serve to illustrate profound mysteries» (Ackerman 1991: 16), «a mystical sense of the unity between all forms of life» ${ }^{4}$, «a kind of celebratory pantheism", como afirma Walford Davies, que hace que el hombre se convierta en "part of an organic, unmourning universe» (Davies 1986: 70).

Sin embargo, es difícil afirmar con seguridad que la poesía de Dylan Thomas sea expresión de la fe en Dios. Parece más bien, como lo expone Clark Emery, la expresión de una búsqueda, «a search never satisfactorily concluded» (Emery 1963: 15). O, en palabras de Ralph Maud:

Thomas's God [...] is not a religious entity at all in the normal sense of a presiding Being whose presence controls or at least justifies our existence. Thomas's God does nothing to alleviate the absurdity of the position of rational man in an irrational universe; Thomas's God does nothing to explain death in terms of higher values. As the eternal sympathetic spectator, He simply weeps, offering none of the usual consolations. [...]His own God has perhaps only one function: to make death less fearful. Or, looked at the other way round, that miraculous force which - not for any arguable reason but nevertheless effectively - makes death less fearful, he calls God. (Maud 1966: 80)

\section{LA DIALÉCTICA DE LAS IMÁGENES}

En el apartado anterior, se ha expuesto cómo la dialéctica de los procesos orgánicos, los ciclos de muerte y resurrección, se erige como el tema principal de la poesía de Dylan Thomas, lo que Walford Davies llama «the nearest thing in Thomas to an overall 'philosophy'» (Davies 1986: 91). En este apartado, se constatará cómo esa dialéctica forma parte esencial, al mismo tiempo, de su método de composición poética.

En la carta a Henry Treece de 23 de marzo de 1938, Thomas explica así su forma de escribir:

${ }^{3}$ Su estudio, Dylan: Druid of the Broken Body, va encarninado, de hecho, a demostrar que existe en la poesía de Dylan Thomas una progresion espiritual hacia el Catolicismo. Para la cita concreta del texto, ver Davies 1977: 35

4 ACKERMAN 1991: 41. También William Empson (1966: 87) afirma: «He really was a 'mystic', as the term is used». 
[...] it consciously is not my method to move concentrically round a central image [...]. A poem by myself needs a host of images, because its centre is a host of images. I make one image - though 'make' is not the word, I let, perhaps, an image be 'made' emotionally in me and then apply to it what intellectual \& critical forces I possess - let it breed another, let that image contradict the first, make, of the third image bred out of the other two together, a fourth contradictory image, and let them all, within my imposed formal limits, conflict. Each image holds within it the seed of its own destruction, and my dialectical method, as I understand it, is a constant building up and breaking down of the images that come out of the central seed, which is itself destructive and constructive at the same time [...]. Out of the inevitable conflict of images - inevitable, because of the creative, recreative, destructive and contradictory nature of the motivating centre, the womb of war - I try to make that momentary peace which is a poem. I do not want a poem of mine, nor can it be, a circular piece of experience placed neatly outside the living stream of time from which it came; a poem of mine is, or should be, a watertight section of the stream that is flowing all ways; all warring images within it should be reconciled for that small stop of time. (Ferries 1985: 281-2)

El hecho de que Dylan Thomas fuera plenamente consciente de esta dialéctica de las imágenes, no es, por supuesto, casual: su método de escritura responde a la misma concepción del universo como una unidad que no cesa de manifestarse en los procesos de creación y destrucción, incluso en el acto mismo de la creación poetica: "The conflicting welter of images which results is his expression of the flux within himself and of the flux in which the phenomenal world is held.» (Stephens 1972: 37), y que constituye también la manifestación de que la experiencia no nos llega a través de un plano discursivo seleccionado de antemano, sino de forma simultánea: «Poetic language is for him [Dylan Thomas] a medium for creating that experience in its simultaneity, variety and unity» (Ibid., pág. 21).

Para Ackerman, esta manifestación se encuentra también unida a una profunda desconfianza en el intelecto:

He seems to have feared the influence of intellectual upon emotional and sensory experience, and consequently is reluctant to impose too rigorous a cerebral control upon his emotional perceptions and upon his imagery. If an experience recorded in one of the poems is confused or conflicting, he accepts that obscurity and wildness. (Ackerman 1991: 43) 
Aunque sería interesante matizar a qué tipo de función del intelecto se refiere Ackerman, el efecto más característico de esta técnica poética es el de compresión en el tiempo: la lectura de un poema de estas características se convierte para el lector en un acto a través del cual experimenta con una especial intensidad la realidad física de la dialéctica inherente a la vida, lo que John Bayley Ilama «[...] the physical reality of 'in my beginning is my end' which of all Thomas's special apprehensions is the one most powerfully conceived and carried out.» (Bayley 1966: 160).

Esta poesía, en la que la linearidad del tiempo aparece totalmente colapsada, se convierte también, como afirma Stewart Crehan, en un acto político: la afirmación, frente a cualquier totalitarismo, de la libertad humana:

The dialectic in its Marxist guise that Hitler tried to murder in 1933, Stalin tried to absorb into 'Socialist Realism', the doctrine of art officially promulgated at the Soviet Writers Congress in 1934, when 18 Poems was published. Thomas was keeping alive imaginatively what fascism and dogmatism had apparently succeeded in killing politically. The rich polysemy and fluidity of his poetic language undermine the apparent fixity of the idea; they show the idea in its abstract form to be merely a string of signifiers, not a reliable truth, so that abstract pseudotruth is replaced by the verbal image. Nor is the image fixed, either. Only when the image does its work at an emotional level, as a material signifier within an associative process originating in the unconscious, and then, crucially, within a contradictory process [...], only then does the image resist decay, remaining the last graspable straw in a world of drowning truths. (Crehan 1990: 53)

Si bien es cierto que esta dialéctica de imágenes es particularmente explosiva en los primeros poemas, y se va atenuando según la poesía de Dylan Thomas evoluciona hacia temas distintos de los relacionados directamente con los procesos orgánicos, hasta llegar a la tristeza y la sensación de soledad que aparecen frecuentemente en los últimos poemas, la técnica continúa siendo empleada en su poesía, aunque, como ya se ha hecho notar, debilitada según se van instalando en ella los temas de la inocencia, la nostalgia del paraíso perdido, la sacralización de la naturaleza, la búsqueda de Dios, etc., es decir, según la poesía evoluciona hacia un mayor conceptualismo.

\section{Otras técnicas poéticas en Dylan thomas}

Además de la confrontación entre imágenes que se contradicen y se afirman, mientras se van engendrando unas a otras, Thomas utiliz 6 en su poesía 
muchas técnicas diferentes. Elder Olson las divide en dos grandes apartados, que llama «Techniques of Depiction» $y$ «Techniques of Language» (Olson 1972: 42-62).

Dentro de las «Techniques of Depiction», Olson distingue «pseudo-dramatic dialogues» de poemas como I see the boys of summer, Find meat on bones, o If my head hurt a hair's foot, y «pseudo-dramatic monologues", como en Before I knocked, My World is Pyramid, o When once the twilight locks no longer. Los efectos que se consiguen a través de esta técnica son múltiples: énfasis en lo concreto, inmediatez, resaltar el contraste entre dos puntos de vista opuestos, o entre motivos y deseos enfrentados, así como un alto grado de economía.

En segundo lugar, se encuentra la técnica de «pseudo-narrative», que aparece sobre todo en los sonetos Altarwise by owl-light, en $A$ Winter's Tale y en Ballad of the Long-Legged Bait. Su efectividad consiste, aparte de la viveza que confiere al poema, en jugar con el ritmo narrativo del poema, a través, por ejemplo, del suspense y lo inesperado.

Otro rasgo característico de los poemas es la ambigüedad circunstancial, que impide saber a ciencia cierta quién es el hablante del poema, qué hace exactamente, quién recibe la acción del verbo, y en qué circunstancias. Un ejemplo de esta ambiguiedad es el escaso número de poemas con título (el título de la mayoría de los Collected Poems suele corresponder al primer verso del poema), cuando en muchos casos, el hecho de haberlos titulado habría sido suficiente para resolver muchas de las perplejidades que su lectura produce.

En cuanto a las «Techniques of Language», Olson distingue, en primer lugar, el uso de palabras de significado múltiple y función sintáctica múltiple, como «fellow» en My World is Pyramid, «wether / weather» o «rung (like a bell) / rung (of a ladder)», "witch / which» en los sonetos Altarwise; el uso constante de juegos de palabras basados en la similitud fonética de las mismas; la mezcla de niveles diferentes de lenguaje(arcaico, literario, vulgar...); la parodia mediante el uso de palabras similares: «minstrel angles» en lugar de «ministering angels», «maid and head» por «maidenhead», «man through macadam» en vez de «man through Adam», etc.

Otra de sus técnicas favoritas es la de acuñar nuevas palabras o inventar nuevos usos para las ya existentes. Destacan los numerosos compuestos creados por él, como «grave-gabbing», «mothers-eyed», «sea-legged», «bird-papped», etc. También, la utilización de sustantivos como verbos, como en el caso del verso «Jacob to the stars», cuyo significado en el poema es «climb Jacob's ladder to the stars".

Destaca, asimismo, el uso de lo que Olson llama «a highly composite metaphor in which the parts are unintelligible until we grasp the whole», y cita los 
ejemplos del uso de «just» y «holy heron» en Over Sir John's Hill, o «Noah» en Author's Prologue.

Otro uso de la metáfora, según Olson, se efectúa a través de los compuestos; por ejemplo, «lamb white days» con el sentido de «days innocent as a lamb is white», o «a springful of larks» para indicar «as many larks as you would find in a whole spring». A veces, una de las partes que forman el término compuesto indica las circunstancias bajo las cuales el otro tuvo lugar; por ejemplo, «sky blue trades» significa «things I busied myself with, as with a trade, under the blue sky», etc.

También encontramos la utilización frecuente de lo que Olson llama «implied or suggested metaphor», que se genera mencionando atributos de un término hasta que se produce una definición aproximada. Otro tipo de metáfora proviene de la transformación de una de las partes que conforman una frase hecha, para producir una analogía que, de alguna forma, se halla implícita; es el caso de «a jaw for news» en lugar de «a nose for news», o de «the stations of the breath» en vez de «the stations of the Cross».

Asimismo, el uso de perífrasis en sus formas más variadas constituye otra de sus técnicas poéticas. Por ejemplo, «a drug-white shower of nerves and food» es una forma de decir «snow» («snow» tanto en el sentido de «nieve», como de «cocaína», como de «maná caído del cielo»), «shafted disk» significa «clock», y «bow-and-arrow birds» es el equivalente de «weathercocks».

Respecto a la sintaxis, sus poemas están llenos de lo que Olson denomina «ambiguous reference, false parallelism, ellipsis (particularly of co-ordinating and subordinating connectives), something that we might call 'false apposition', and something else that we may call 'delayed complement'». Además de todo ello, tales ambigüedades aumentan por el uso, que en ocasiones llega a parecer caprichoso, de los signos de puntuación.

Por su parte, Gareth Thomas (1990: 65-86) realiza el siguiente análisis de las técnicas lingüísticas de la poesía de Dylan Thomas:

- A nivel fonológico, en el cual la influencia superficial de Hopkins resulta más evidente, se encuentra el uso exhaustivo de aliteraciones, onomatopeyas, estructuras rítmicas y rimas de todo tipo. En cuanto al ritmo, Thomas suele emplear la acumulación de detalles para crear un crescendo que puede ser indicativo de la influencia del estilo de los predicadores galeses. Con respecto a las rimas, Thomas experimenta continuamente con nuevas posibilidades, no siempre con fortuna; el caso más extremo es el poema Author's Prologue, en el que los 102 versos riman de fuera hacia dentro (es decir, el 1 con el 102, el 2 con el 101, el 3 con el 100 , y así sucesivamente), hasta coincidir en los versos centrales. 
- A nivel semántico y gramatical, las ambigüedades producidas por los juegos de palabras, el uso de sustantivos como verbos que a su vez se transforman en adjetivos a través del participio de presente o de pasado (como en «vowelled beeches», por ejemplo) dan lugar a una indeterminación del significado que puede llegar a ser exasperante.

- En relación con el tema de la sintaxis, una de las mayores críticas que suelen hacerse a los poemas de Dylan Thomas es que en ellos no aparece una progresión del pensamiento desde la primera línea a la última, sino una serie de reiteraciones. La pregunta que se hace $\mathrm{Ga}$ reth Thomas ante esta línea de argumentación es también una respuesta:

But what if the re-phrasings, the re-statements, the qualifications, the parentheses, $[\ldots]$ are in fact accurately miming a movement of the mind - a mind often near to despair at the apparent impossibility of genuine communication [...] about a human condition where pain seems to be suffered so casually and so separately? (Thomas 1990: 76-77)

En resumen, de los análisis de Elder Olson y Gareth Thomas se deduce que existe en Dylan Thomas el empleo de técnicas cuyo efecto principal sobre el lector es, en muchos casos, la ininteligibilidad del poema, al menos a un nivel consciente. Que estas técnicas eran empleadas de modo deliberado por Dylan Thomas lo demuestra la siguiente respuesta a un cuestionario enviado por un estudiante:

To your third question - Do I deliberately utilise devices of rhyme, rhythm and word formation in my writing - I must, of course, answer with an immediate, Yes. I am a painstaking, conscientious, involved and devious craftsman in words, however unsuccesful the result so often appears, and to whatever wrong uses I may apply my technical paraphemalia, I use everything and anything to make my poems work and move in the directions I want them to: old tricks, new tricks, puns, portmanteau-words, paradox, allusion, paranomasia, paragram, catachresis, slang, assonantal rhymes, vowel rhymes, sprung rhythm. Every device there is in language is there to be used if you will. (Fitzgibbon 1987: 371)

Es bien conocida la indignación de Dylan Thomas ante quienes consideraban que su poesía carecía de control por parte del autor. En la carta a Henry Treece de 16 de Mayo de 1938 afirma: 
Stephen Spender, by the way, said in a review of the year's poetry some time ago - in the Daily Worker - 'The truth is that Thomas's poetry is turned on like a tap; it is just poetic stuff with no beginning nor end, shape, or intelligent and intelligible control'. [...] Spender's remark is really the exact opposite of what is true. My poems ARE formed; they are not turned on like a tap at all, they are 'watertight compartments'. Much of the obscurity is due to rigorous compression; the last thing they do is to flow; they are much rather hewn ${ }^{5}$.

Desde la publicación en 1957 de las cartas escritas por Dylan Thomas a su amigo y poeta Vernon Watkins, es asimismo bien conocida su laboriosidad y meticulosidad a la hora de escribir, así como su preocupación por el significado de las palabras. Como lo expresa C.B. Cox, «His discussions with Watkins show that he knew precisely what effects he intended, and to some degree justify his controversial claim that his poems should be read 'literally'.» (Cox 1966: 2).

Del mismo modo, las cartas a Pamela Hansford Johnson, Margaret Taylor $y$ otros ${ }^{6}$ dan cuenta de las interminables horas de trabajo empleadas en cada uno de los versos, de los cientos de borradores, de las semanas e incluso meses que solía llevarle la configuración definitiva de un poema. El análisis de la evolución de los borradores de Poem on His Birthday realizado por John Ackerman (1991: 149-155) y David Holbrook (1972b: 181-189), así como la comparación entre las versiones de los Notebook Poems y las definitivas de Collected Poems, muestra cómo, según avanza el poema. Thomas le va imponiendo variantes fonéticas, imagísticas o semánticas que aumentan, simultáneamente, la oscuridad racional del mismo.

Es posible, en consecuencia, preguntarse: ¿Por qué el poeta oscurece deliberadamente el acceso racional a sus poemas? ¿Son sus poemas la manifestación del funcionamiento patológico de un individuo esquizoide "? ¿Se trata, tal vez, del deseo perverso de tomar el pelo a los lectores? ¿O existe alguna razón que, al igual que hemos visto para la técnica de la dialéctica de las imágenes, justifique también esta aparente falta de sentido?

El apartado siguiente intenta responder a estas cuestiones.

5 Véase FerRIEs 1987: 297-8. Para las numerosas defensas que hace Dylan Thomas de su poesía contra quienes le acusaban de practicar la técnica surrealista de la escritura automática, ver también las páginas 51, 58, 90, 204-5, 210, 231, 297-8, 302.

${ }^{6}$ Ver, por ejemplo, FERrIEs 1987: 114, 130, 182, 223, 298, 651

${ }^{7}$ Esta es la tesis que sostiene DAvid Holbrook en su libro Dylan Thomas. The Code of Night. Ver HolbroOK 1972a. 


\section{La POEsIa de Dylan Thomas: un CAMINo de EXPLORACIÓN} DEL INCONSCIENTE

En 1934, la revista New Verse publicó las respuestas a un cuestionario que había enviado a sus colaboradores. La pregunta número 4 era: «Have you been influenced by Freud and how do you regard him?». Esta fue la respuesta de Thomas:

Yes. Whatever is hidden should be made naked. To be stripped of darkness is to be clean, to strip of darkness is to make clean. Poetry, recording the stripping of the individual darkness, must, inevitably, cast light upon what has been hidden for too long, and, by so doing, make clean the naked exposure. Freud cast light on a little of the darkness he had exposed. Benefiting by the sight of the light and the knowledge of the hidden nakedness, poetry must drag further into the clean nakedness of light more even of the hidden causes than Freud could realise. ((Fitzgibbon 1987: 162)

El hecho de que Thomas admita la influencia de Freud, no debe sin embargo hacernos sobrevalorar esta influencia. En el documento que se ha dado en llamar su «Poetic Manifesto», responde así a la pregunta de si Freud constituye una de las principales influencias en su obra:

My only acquaintance with the theories and discoveries of $\mathrm{Dr}$ Freud has been through the work of novelists who have been excited by his case-book histories, of popular newspaper scientific-potboilers who have, I imagine, vulgarised his work beyond recognition, and of a few modern poets, including Auden, who have attempted to use psychoanalitical phraseology and theory in some of their poems.

I have read only one book of Freud's, The Interpretation of Dreams, and do not recall having been influenced by it in any way. Again, no honest writer today can possibly avoid being influenced by Freud through his pioneering work into the Unconscious [...] (Ibid., 370-1)

Los poemas de Dylan Thomas corroboran esta afirmación: aunque algunos de ellos son relatos de sueños, y aunque utilicen técnicas de condensación, desplazamiento y simbolización similares a las descritas por Freud, su influencia parece limitarse a añadir una nueva dimensión a los símbolos tomados de la Biblia y del folklore universal, que constituyen su fuente más importante (Daiches 1966: 24). Esta dimensión freudiana la vemos, por ejemplo, en $\mathrm{Ba}$ llad of the Long-Legged Bait, donde el ancla, las olas, la caña, las criaturas que 
el cebo atrae, adquieren connotaciones sexuales claras. En «The Universe of the Early Poems», Elder Olson afirma respecto al uso de símbolos freudianos en Dylan Thomas:

Whereas, for Freud, fruit symbolizes the female breast and definitely does not symbolize offspring, it is generally a child-symbol for Thomas (as indeed it is in common discourse). Whereas, for Freud, caves, churches, and chapels refer to the female genitalia, Thomas uses caves to signify the innermost recesses of the self, and curches and chapels - particularly sunken ones - to signify lost pristine faiths. Thomas associates ladders and climbing, not with sexual intercourse, but with man's spiritual ascent. (Olson 1966: 49)

Si la función de la poesía debe ser, como afirma Thomas, sacar a la luz las fuerzas ocultas que Freud había comenzado a explorar, ¿no es lícito pensar, entonces, que su actitud hacia el lenguaje, el uso recurrente de la ambigüedad y la indeterminación del sentido, la simultaneidad incluso de significados opuestos en una misma palabra y en una misma frase, y todas las técnicas habituales de sus poemas, constituyen el medio del cual se vale para esta exploración del inconsciente, para este sacar a la luz lo que John Wain (1972: 13) denomina «the power that humanity has stored in language»? Stewart Crehan afirma acertadamente: «Like Blake, he recognized that the poetic genius (which is not restricted to poets) explores deeper experiences than those available to the empiricist and the rationalist.» (Crehan 1990: 36)

El hecho de que esta exploración resultara para Dylan Thomas una labor ardua, laboriosa, metódica, exasperante hasta el extremo de llegar a producirle dolor físico ${ }^{8}$, demuestra hasta qué punto era la base misma de su concepto de la poesía: a través de sus versos, Thomas intenta transmitimos una experiencia que, al igual que sucede con la experiencia mística ${ }^{9}$, está, paradojicamente, más allá de las palabras.

8 En la carta del 9 de Mayo de 1934 a Pamela Hansford Johnson, Dylan Thomas dice: «The old fertile days are gone, and now a poem is the hardest and most thankless act of creation. [...] It gives me now a physical pain to write poetry. I feel all my muscles contract as I try to drag out, from the whirlpooling words around my everlasting ideas of the importance of dh on the living, some connected words that will explain how the starry system of the dead is seen, ord physical pain, grave's sky, along the orbit of a foot or a flower. [...] And I could scream, wh a Sanskrit limerick. I when a line of mine is seen naked on paper \& seen to be as meaningless as a shall never be understood.m Véase Ferries 1987: 130

admite en varias ocasiones su interes por la mística. Ver, por ejemplo, FERRIES 1987: 26, 77, 86 («A mystic is a man who takes things literally», dice. La frase, obviamente. nos recuerda sus frecuentes advertencias respecto a que sus poemas debian ser leídos «literally»). 
A pesar de que Dylan Thomas negó siempre su pertenencia al movimiento surrealista, basándose principalmente en que él rechazaba la técnica de la «escritura automática», existen puntos en común derivados sobre todo de este interés por el inconsciente, y de la utilización de un lenguaje que no apela, en primera instancia, a la comprensión racional. De hecho, como es sabido, la presencia del irracionalismo en la poesía contemporánea ha ido en aumento desde Baudelaire, y constituye uno de los rasgos más característicos y más «hondamente revolucionarios» (Bousoño 1985: 191) de la misma.

\section{REFERENCIAS BIBLIOGRÁFICAS}

ACKerman, John (1991): Dylan Thomas, His Life and Work, 4." ed., Londres, Macmillan.

BAYLEY, John (1966): «Dylan Thomas», en Cox 1966a.

Bold, Alan (ed.) (1990): Dylan Thomas: Craft or Sullen Art, Londres, Vision Press Ltd. y Nueva York, St. Martin's Press, Inc.

Bousoño, Carlos (1985): Teoría de la expresión poética, 7. ${ }^{\mathrm{a}}$ ed., Madrid, Gredos.

Cox, C. B. (ed.) (1966): Dylan Thomas, A Collection of Critical Essays, Nueva Jersey, Prentice-Hall, Inc.

CREHAN, Stewart (1990): «The Lips of Time», en Bold 1990.

DAICHES, David (1966): «The Poetry of Dylan Thomas», en Cox 1966.

DaviEs, Aneirin Talfan (1977): Dylan: Druid of the Broken Body, 2. ${ }^{a}$ ed., Swansea, Christopher Davies.

DAviEs, Walford (ed.) (1972): Dylan Thomas, New Critical Essays, Londres, J. M. Dent \& Sons.

- (1986): Dylan Thomas, Milton Keynes-Filadelfia, Open University Press.

EMERY, Clark (1963): The World of Dylan Thomas, Florida, University of Miami Press.

EMPSON, William (1966): «Collected Poems and Under Milk Wood», en Cox 1966. FERrIs, Paul (ed.) (1985): Dylan Thomas: The Collected Letters, Londres, J. M. Dent \& Sons.

- (1987): Dylan Thomas, Londres, Paladin Grafton Books y Penguin Books.

FrtzGiBbon, Constantine (1987): The Life of Dylan Thomas, Londres, Plantin Paperbacks.

Ver también las páginas 91 («a man who believes in the supernatural is a man who takes things literally») y 189 («Poetry, Jacobean and Metaphysical, and music, minus the more intricate technicalities, mysticism (honest), and psychology (abnormal for preference) are, for Purpose's purpose, about the only things I appreciate sufficiently.») 
HolBrook, David (1972 ): Dylan Thomas: The Code of Night, Londres, The Athlone Press.

- (1972b): «The Code of Night: The 'Schizoid Diagnosis' and Dylan Thomas», en Davies 1972.

KoRG, Jacob (1990): «Dylan Thomas's Concept of the Poet», en Bold 1990.

Maud, Ralph (1966): «Last Poems», en Cox 1966.

Moynihan, W. T. (1966): The Craft and Art of Dylan Thomas, Oxford y Nueva York, Oxford University Press.

Olson, Elder (1966): «The Universe of the Early Poems», en Cox 1966.

- (1972): The Poetry of Dylan Thomas, 8." ed., Chicago, University of Chicago Press.

SHAPIRO, Karl (1966): «Dylan Thomas», en Cox 1966.

STEPHENS, Raymond (1972): «Self and World: The Earlier Poems», en Davies 1972.

ThомAS, Gareth (1990): «A Freak User of Words», en Bold 1990.

Tindall, William York (1961): A Reader's Guide to Dylan Thomas, Nueva York, Farrar, Strauss and Cudahy.

WaIN, John (1966): «Dylan Thomas: A Review of His Collected Poems», en Cox 1966. 